\title{
IDENTIFICATION OF FRESHWATER GOBY SPECIES FROM THE BIAK AND KOYOAN RIVERS, LUWUK BANGGAI, CENTRAL SULAWESI
}

\author{
Abdul Gani ${ }^{1}$, Achmad Afif Bakri ${ }^{2}$, Devita Tetra Adriany ${ }^{3}$, Nurjirana ${ }^{4}$, Muh. Herjayanto ${ }^{5}$, Monicha Indrasari \\ Bungalim $^{6}$, Samliok Ndobe ${ }^{7}, \&$ Andi Iqbal Burhanuddin ${ }^{8}$
}

Submitted: July 28, 2019, Accepted: November 11, 2019

\begin{abstract}
${ }^{1,6}$ Aquaculture Study Program, University of Muhammadiyah, Luwuk Banggai, Indonesia
${ }^{2,3}$ Fish Quarantine, Quality Control and Fisheries Product Safety Station, Luwuk Banggai, Indonesia

${ }^{4}$ Fisheries Department, Faculty of Marine Science and Fisheries, University of Hasanuddin, Makassar, Indonesia

${ }^{5}$ Fisheries Study Program, Faculty of Agriculture, Universitas Sultan Ageng Tirtayasa, Banten, Indonesia

${ }^{7}$ Aquaculture Study Program, Faculty of Animal Husbandry and Fisheries, Universitas Tadulako, Palu, Indonesia

${ }^{8}$ Marine Science Department, Faculty of Marine Science and Fisheries, Universitas Hasanuddin, Makassar, Indonesia

Corresponding Author:

Abdul Gani

Email: abdulgani273085@gmail.com
\end{abstract}

\begin{abstract}
Sulawesi is an island famous for its biodiversity, including many endemic species. In particular, Sulawesi has the highest number of gobies in the world, including species with potential as food and/or ornamental fishes. The exploration of freshwater ichthyofauna is important in the context of Indonesian and global biodiversity. This research aimed to identify gobies found in the Luwuk Banggai area of Central Sulawesi, as a contribution to the exploration of Indonesian ichthyofaunal biodiversity. Gobies were sampled from January to March 2019 in the Biak and Koyoan Rivers. The sampled fish were measured and identified based on morphological characteristics. A total of 52 specimens were collected, and identified as belonging to 17 species within two families, the Gobiidae and Eleotridae. Gobies from the Koyoan River comprised 32 specimens from 8 species, while 20 specimens belonging to species were found in the Biak River. Only two species were found in both rivers: Stiphodon semoni and Sicyopterus lagocephalus. These results augment the body of knowledge regarding the presence and distribution of gobies in Indonesia.
\end{abstract}

Key words: biodiversity, Gobiidae, Eleotridae, Luwuk Banggai.

\section{INTRODUCTION}

Indonesia is a tropical country blessed with highly diverse flora and fauna, including ichthyofauna (Lamoureux et al., 2006; Hoffman et al., 2010; Hubert et al., 2015). As an archipelagic nation spread across three time zones and bisected by the equator, the freshwater ichthyofauna of Indonesia is concentrated in several of the larger islands, with a high mean species density of 0.6 species per $1000 \mathrm{~km}^{2}$ (Hubert et al., 2015). To put this in perspective, two renowned biodiversity hotspots, Brazil and the Democratic Republic of the Congo, have freshwater ichthyofaunal densities of 0.37 and 0.48 species per $1000 \mathrm{~km}^{2}$, respectively (Hubert et al., 2015). The Indonesian Island of Sulawesi is particularly rich in endemic freshwater fishes. Kottelat (1990) lists 62 species of freshwater fishes found in Sulawesi, of which 52 are endemic to the island.

The gobies are a group of fishes with considerable, albeit often underestimated, potential as fisheries resources. In addition to their role as often locally important food fishes, many gobies also have potential as ornamental fishes, due to their attractive shapes and colouration. The City of Luwuk, capital of the Luwuk Banggai District in Central Sulawesi, is known as the watery city, because of the many rivers flowing into the sea all along the coast. Each of these rivers has its own ichthyofauna, including gobies. The aim of this research was to find and identify gobies living in the rivers of the Luwuk Banggai region of Central Sulawesi as a contribution towards the inventory of fish species richness and diversity in Indonesia.

\section{MATERIALS AND METHODS}

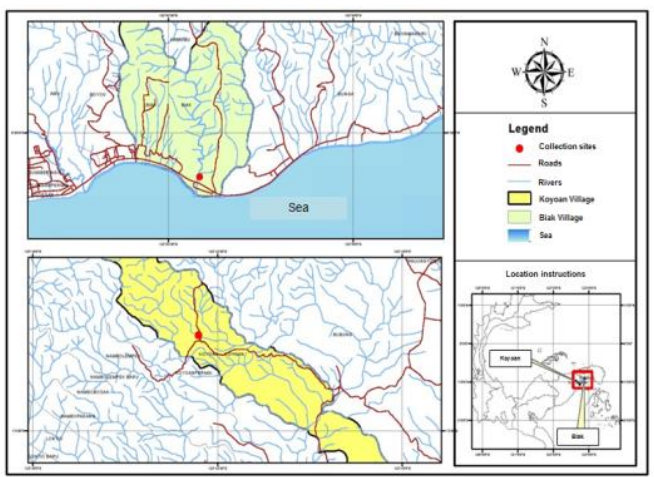

Figure 1.Goby collection sites in Luwuk Banggai, Central Sulawesi, Indonesia. The red dots indicate the collection sites on the Biak River in Biak Village (Desa Biak, above) and Koyoan River in Koyoan Village (Desa Koyoan, below).

This research was carried out between January and March 2019 in the Luwuk Banggai region of Central 
Sulawesi. The sampling sites were in the Koyoan and Biak Rivers (Figure 1).

Specimens were collected using a scoop net. Each specimen was photographed (digital camera), euthanised and preserved in $70 \%$ alcohol. The specimens were identified to the lowest possible taxonomic level (species or genus) based on references inlcuding Carpenter and Niem (2001), Keith et al.,(2015) and FishBase, the global database of fishes (Froese and Pauly, 2019).

Table 1. Number and species of the goby specimens collected from the Biak and Koyoan Rivers

\begin{tabular}{|c|c|c|c|}
\hline Site & Species & $\begin{array}{l}\text { Number of } \\
\text { Specimens }\end{array}$ & Total \\
\hline \multirow{10}{*}{$\begin{array}{l}\text { Biak } \\
\text { River }\end{array}$} & $\begin{array}{l}\text { Sicyopterus } \\
\text { lagocephalus }\end{array}$ & 1 & \multirow{10}{*}{20} \\
\hline & Sicyopterus longifilis & 1 & \\
\hline & Stiphodon semoni & 10 & \\
\hline & Awaous sp. & 1 & \\
\hline & Schismatogobius sp. & 1 & \\
\hline & Stenogobius spp. & 2 & \\
\hline & $\begin{array}{l}\text { Belobranchus } \\
\text { belobranchus }\end{array}$ & 1 & \\
\hline & Eleotris fusca & 1 & \\
\hline & Eleotris sp1 & 1 & \\
\hline & Eleotris sp2. & 1 & \\
\hline \multirow{8}{*}{$\begin{array}{l}\text { Koyoan } \\
\text { River }\end{array}$} & Sicyopterus sp. & 2 & \multirow{8}{*}{32} \\
\hline & $\begin{array}{l}\text { Sicyopterus } \\
\text { lagocephalus }\end{array}$ & 1 & \\
\hline & $\begin{array}{l}\text { Sicyopus } \\
\text { zosterophorus }\end{array}$ & 12 & \\
\hline & Sicyopus sp. & 1 & \\
\hline & $\begin{array}{l}\text { Sicyopus } \\
\text { discordipinnis }\end{array}$ & 1 & \\
\hline & Stiphodon semoni & 8 & \\
\hline & $\begin{array}{l}\text { Lentipes } \\
\text { mekonggaensis }\end{array}$ & 6 & \\
\hline & Lentipes sp. & 1 & \\
\hline
\end{tabular}

\section{RESULTS AND DISCUSSION}

The goby specimens found at the two study sites (Table 1) show that ten species from 7 genera (Sicyopterus, Stiphodon, Schismatogobius, Awaous, Stenogobius, Eleotris, and Belobranchus) were found in the Biak River. In the Koyoan River, eight species were found, belonging to four genera (Sicyopterus, Sicyopus, Stiphodon, and Lentipes). At each research site, gobies were present in all riverine habitats along each of the two rivers.

Species belonging to the Eleotridae family ( $B$. branchus, E. fusca, Eleotris sp1, and Eleotris sp2.) were only found in the Biak River (Figure 2). This was likely related to the habitat types present, in particular the presence of muddy bottomed areas, a feature known as a favoured habitat criteria for the Eleotridae, in particular the members of this family commonly found in Indonesia. This habitat preference is described in
Hubert et al. (2015) who found members of the Eleotridae in all the fresh water bodies they sampled in Indonesia.
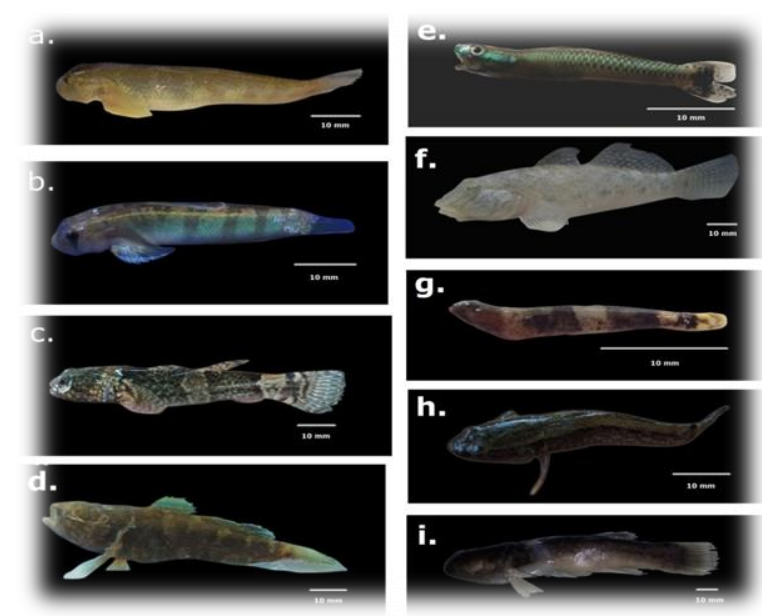

Figure 2. Goby species found in the Biak River: a. Sicyopterus lagocephalus; b. S. longifilis; c. Belobranchus belobranchus; d. Eleotris sp1.; e. Stiphodon semoni; f. Awaous sp.;
Schismatogobius sp.; h. E. fusca; i. Eleotris sp2.
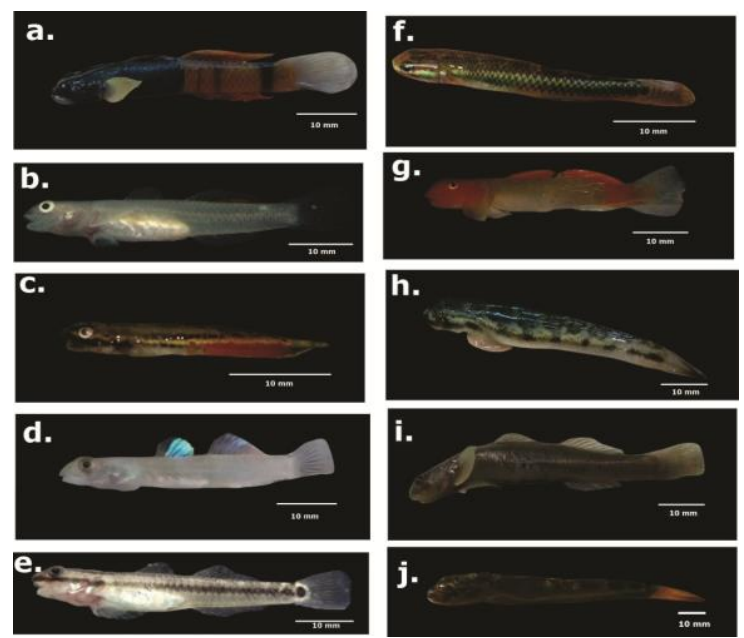

Figure 3. Goby species found in the Koyoan River: a. Sicyopus zosterophorus (male); b. S. zosterophorus (female); c. S. discordipinnis; d. Sicyopus sp.; e. Stiphodon semoni (male); f. S. semoni (female); g. Lentipes mekonggaensis; $\mathrm{h}$. Sicyopterus sp.; i. Lentipes sp. (female); j. Sicyopterus lagocephalus.

All the species found in the Koyoan River (Figure 3) belong to the subfamily Sicydiinae. The Koyoan River is one of several rivers in the Luwuk Banggai area with waterfalls and rapids (Figure 4). Such features are known to be a habitat characteristic preferred by members of the subfamily Sicydiinae. According to Keith et al. (2003), during the upstream (amphidromous) migration of goby postlarvae, the majority of postlarvae stop and settle when they come to areas with waterfalls or rapids, which can provide them with ideal habitat. After adult gobies spawn in the river, the currents carry the embrios towards the sea where the larvae will undergo a planktonic larval phase. Once they reach the postlarval phase, the young gobies 
will migrate back towards rivers and streams to grow, mature, and spawn (McDowall, 2007; Keith et al., 2008).

Gobies of the subfamily Sicydiinae have a special adaptation, in the form of modified ventral fins, to enable them to climb up waterfalls. Their ventral fins are fused to form a sucker which enables them to attach themselves to rocks or other hard substrate. They use both their mouths and this sucker to climb upstream, making their way against strong, fast-flowing currents. Keith et al. (2003) report that the combination of these modified ventral fins and strong, well-developed pectoral fins can even enable goby species in the Sicydiinae subfamily to climb cliffs with fast-flowing waterfalls cascading down them. This ability enables members of the Sicydiinae subfamily to inhabit the upstream areas of watercourses, where they can be found in hilly or mountainous areas more than $100 \mathrm{~m}$ above sea level (Keith et al., 2015). According to Ebner et al. (2011), the Sicydiinae subfamily is a group of gobies with a high species diversity in the tropical IndoPacific region.

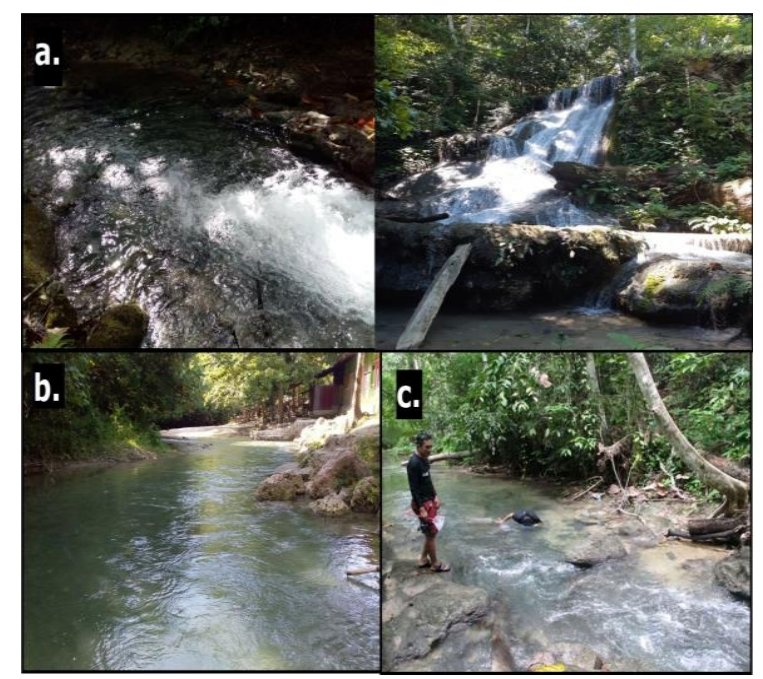

Figure 4. The goby collection sites: a. Koyoan River; b. Biak River; c. Goby collection

The genus Schismatogobius comprises 24 known species worldwide (www.fishbase.org), 8 of which are found in Indonesia, with reported distributions in Sumatra, Java, Bali, Lombok, Ambon, and Sulawesi (Keith et al, 2017; Nurjirana et al., 2019). The species L. mekonggaensis found in the Koyoan River is a recently described species which was first found in 2014 in the Mekongga Mountains of Southeast Sulawesi Tenggara and has only been reported previously from that location (Keith et al., 2014). The species S. discordipinnis was originally found and described from Papua New Guinea by Watson (1995), and has since been reported from several other sites including Irian Jaya (Keith et al.,2015), Australia (Ebner et al.,2011), and the Solomon Islands (Boseto et al.,2007; Polhemus et al., 2008).

Out of the 17 species found in this study, only two species, S. semoni and S. Lagocephalus, were found in both the study sites. Keith et al. (2015) reports both $S$. semoni and S. lagocephalus as species which are widely distributed across Indonesia and even more widely within the Indo-Pacific region. In general, these gobies are relatively adaptable, which is one reason why they can be found in almost all aquatic habitat types in Indonesia, albeit with varying levels of abundance.

\section{CONCLUSION}

The results of this study show that the 52 goby specimens collected from the Biak River and Koyoan River in Luwuk Banggai, Central Sulawesi, Indonesia belong to 17 species. Research to explore the species diversity of freshwater fishes, in particular gobies, contributes to the body of knowledge on the species richness of Indonesian ichthyofauna. Such research has the potential to find new species as well as improving knowledge regarding the distribution of known species (new records).

\section{ACKNOWLEDGMENT}

The authors wish to thank all who took part in or provided support for this research. Dr. Abigail M. Moore who helped correct this manuscript.

\section{REFERENCES}

Boseto, D., Morrison, C., Pikacha, P. and Pitakia, T. 2007. Biodiversity and conservation of freshwater fishes in selected river on Choiseul Island, Solomon Islands. South Pacific Journal of Natural Science 3: 16-21.

Carpenter, K.E. and Niem, V.H. 2001. FAO Species Identification Guide For Fishery Purposes: The Living Marine Resources of the Western Central Pacific. Vol 6. Bony Fishes Part 4 (Labridae to Latimeriidae), estuarine crocodiles, sea turtles, sea snakes, and marine mammals. FAO, Rome. Pp. 3381-4218.

Ebner B. C., Thuesen P. A., Larson H. K. and Keith P. 2011 A review of distribution, field observations and precautionary conservation requirements for sicydiine gobies in Australia. Cybium 35(4): 397-414.

Froese, R. and Pauly, D. 2019. FishBase, The Global Database of Fishes. http://www.fishbase.org [accessed on 20 March 2019].

Hoffman, M., Hilton-Taylor, C., Angulo, A., Bohm, M., Brooks, T.M. and Butchart, S.H.M. 2010. The Impact of Conservation on the Status of the World's Vertebrates. Science 330: 1503-1509.

Hubert, N., Kadarusman, Wibowo, A., Busson, F., Caruso, D., Sulandari, S., Nafiqoh, N., Pouyaud, L., Ruber, L., Avarre, JM., Herder, F., Hanner, R., Keith, P., and Hadiaty, R. K. 2015. DNA Barcoding Indonesian freshwater fishes: challenges and prospects. DNA Barcodes 3(1): 144-169. 
Keith, P., 2003. Biology and ecology of amphidromous gobiidae of the Indo-Pacific and Caribbean regions. Journal of Fish Biology 63: 831-847.

Keith, P., Hoareau, T. ., Lord, C., Ah-Yane, O., Gimonneau, G., Robinet, T. and Valade, P. 2008. Characterisation of post-larval to juvenile stages, metamorphosis and recruitment of an amphidromous goby, Sicyopterus lagocephalus (Pallas) (Teleostei: Gobiidae: Sicydiinae). Marine and Freshwater Research 59: 876-889.

Keith, P., Hadiaty, R., Hubert, N., Busson, F. and Lord, C. 2014. Three new species of Lentipes from Indonesia (Gobiidae). Cybium 38(2): 133-146.

Keith, P., Lord, C., and Maeda, K. 2015. Indo-Pacific Sicydiine Gobies: Biodiversity, Life Traits and Conservation. $256 \mathrm{p}$.

Keith P., Lord C., Darhuddin H., Limmon G., Sukmono T., Hadiaty R. and Hubert N. 2017 Schismatogobius (Gobiidae) from Indonesia, with description of four new species. Cybium 41(2): 195-211.

Kottelat, M. 1990. Synopsis of the endangered Buntingi (Osteichthyes: Andranichtyidae and Oryziidae) of Lake Poso, Central Sulawesi, Indonesia, with a new reproductive guild and descriptions of three new species. Ichthyological Exploration of Freshwater 1(1): 49-67

Lamoureux, J.F., Morrison J.C., Ricketts T.H., Olson, D.M., Dinerstein, E. and McKnight, M. 2006. Global tests of Biodiversity Concordance and the Importance of Endemism. Nature 440: 212214.

McDowall, R.M., 2007. On amphidromy, a distinct form of diadromy in aquatic organisms. Fish and Fisheries 8: 1-13.

Nurjirana, Burhanuddin, A.I. and Haris, A. 2018. Diversity of penja fish (amphidromous goby) in Leppangan River, West Sulawesi, Indonesia. AACL Bioflux 12(1): 246-249.

Polhemus, D.A., Englund, R.A., Allen, G.R., Boseto, D. and Polhemus, J.T. 2008. Freshwater Biotas of the Solomon Islands Analysis of Richness, Endemism and Threats. Pacific Biological Survey, Bishop Museum. Bishop Museum Technical Report No. 45. Bishop Museum Press, Honolulu. Hawai'i. 126 p.

Watson, R.E. 1995. A new species of Sicyopus from Papua New Guinea with a redescription of Sicyopus multisquamatus (Teleostei: Gobiidae: Sicydiinae). Ichthyological Exploration of Freshwater 6(3): 267-278. 